\title{
Articles
}

\section{Never let a Crisis go to Waste: Politics, Personality and Judicial Self-Government in Ireland}

\author{
By Patrick $O^{\prime}$ Brien $^{*}$
}

\begin{abstract}
Although Ireland is often cited as part of the vanguard of countries adopting forms of judicial self-governance in the 1990s, this appearance can be misleading: the Irish judiciary are self-governing only in limited respects. The judge-led Court Service is in charge of court estate, non-judicial personnel and provision of information on the court system to the public. Many key matters - discipline, promotions and deployment - remain largely out of the control of the corporate judiciary. Judicial appointments are significantly at the discretion of the government. In the last decade, there have been significant moves towards a more corporate judiciary and these are reflected in the creation of a judges' representative body, the Association of Judges of Ireland, and a shadow Judges Council. There are currently proposals to create a new independent mechanism for appointing judges and to create a Judicial Council with a significant role in disciplining the judiciary.

The Irish experience highlights the importance of political and cultural factors in establishing and maintaining judicial independence and self-governance. Despite the significant role for the government in judicial appointments, and the presence of a culture of political patronage in these appointments, there is nonetheless a robust culture of individual judicial independence once judges have been appointed. The creation of the Courts Service in 1999 was a significant transfer of administrative power to the judiciary but it was approved without demur by the political branches, who welcomed the depoliticization of controversial decisions about court estate. Conversely, reforms to judicial appointments have been weak because politicians saw value in maintaining a relatively harmless form of political patronage, and proposals for a Judicial Council that have agreed in outline for two decades have yet to be enacted, apparently because they lack sufficient political salience. The defence of judicial independence, and the creation of robust institutional mechanisms for defending it, ultimately requires the goodwill of politicians.
\end{abstract}

\footnotetext{
* Dr Patrick O'Brien, Lecturer in Law, Oxford Brookes University; patrick.obrien@brookes.ac.uk. I am grateful to Sahba Mohtadi for research assistance and to David Kosar and other members of the JUDI-ARCH project for very helpful comments and suggestions. The research leading to this article has received funding from the European Research Council (ERC) under the European Union's Horizon 2020 research and innovation programme (grant no. 678375- JUDI-ARCH-ERC-2015-STG).
} 


\section{A. Introduction}

The Irish judiciary are self-governing only in a limited respect. Just as in many other common law countries and 'old' democracies, judges historically controlled only their own judgments, court rules and the case listing process. Since 1999 they have formally led the Courts Service, controlling the administration and management of the courts, but relations between the judiciary and Government still appear to play our largely informally, through quiet back-channel communications about pay and conditions, or legally, through court judgments that have enforced a very robust understanding of the separation of powers. There are significant legal protections for the judiciary in the Constitution and statute, and robust cultural respect for judicial independence within politics. Ireland does not, however, fit into any neat theoretical framework that explains either its current judicial arrangements or processes of reform. Judicial administration is a patchwork that has developed in two very broad stages. The initial stage - of (relatively benign) neglect - arose immediately after independence from the United Kingdom in 1922. It was to last for eight decades. The second stage - of ad hoc reform - began in the mid-1990s. This reform stage was driven initially by responses to specific problems (some political, some technocratic) but in the last decade has taken place against a backdrop of institutional restlessness that has affected Irish politics in general as a result of the economic crisis that unfolded from 2007 onwards. The economic crisis prompted a crisis of relations between judges and the political system. Although relations appear to have been mostly repaired the system remains in flux, and new reforms (to judicial appointments, and judicial self-governance) are currently being debated. At this moment, Ireland appears to be moving towards a model that mixes judicial self-governance in some areas with greater formalization, independence and depoliticization in others.

This article argues that Ireland confirms the general conclusions in the literature on judicial independence: that a culture of independence and political respect for the role of the judiciary is more important than formal controls. Nonetheless, Ireland is a small jurisdiction in which relations between judges and the government have proven to be acutely dependent on personality. Reform, in particular, only happens where there are significant political reasons to justify it. Part B of the paper aims to give the reader an overview of the Irish judicial system, and sketches out key institutional features (together with some proposed reforms) as well as the operation of the separation of powers doctrine. This sketch is set against data on public trust in the judiciary in Ireland. Part C will focus on the processes of court reform, drawing on the political history of reform efforts to show that reform only occurs where politicians can be convinced that it is in their interests to sponsor it. Part D will show that judicial independence in Ireland is potentially fragile and dependent to a significant extent on good personal relationships between politicians and judges. The essential relationships between government and the judiciary can be difficult to operate if personal relationships break down (as they did between 2011 and 2013). The article concludes that Ireland exemplifies the paradox of judicial independence: 
judicial independence aims at isolating judges from politics, but depends for its survival on politics and personality. ${ }^{1}$

\section{B. Judges and the court system in Ireland: a sketch}

\section{Key institutions, agencies and functions}

The traditional core judicial functions in Ireland are the conduct and disposal of cases in court, case listing (allocation of cases to judges) and the regulations of court processes and procedures through the rules of court. Within this environment, the key players are the Chief Justice and the Presidents of the District Court, Circuit Court and Court of Appeal.

Figure 1: Structure of the Irish court hierarchy (with head of court)

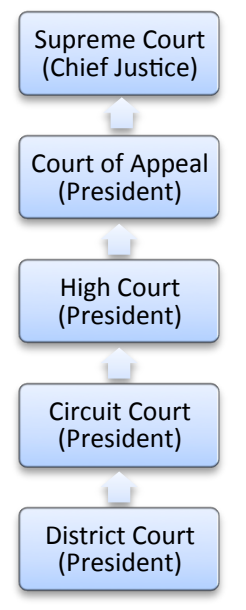

These judicial leaders have a role in case listing and take seats ex officio on the Board of the Courts Service. They also have an informal role in relation to discipline and representation of the judiciary and their courts with the political branches of government. However, the Chief Justice and Presidents have little or no management function in respect of their judicial colleagues, and none in relation to deployment, promotions or appointments (although it is proposed that they will have a role on the new Judicial Appointments Commission; discussed below). Through the common law system, Ireland has inherited a very strong cultural conception of individual judicial independence, which has traditionally overshadowed corporate or collective judicial independence. There is thus

\footnotetext{
${ }^{1}$ For the argument that judicial independence is ultimately a political achievement, see GraHAM GEE ET AL, THE POLITICS OF JUDICIAL INDEPENDENCE IN THE UK'S CHANGING CONSTITUTION (2015).
} 
minimal internal accountability owed by individual judges to their court President or to the Chief Justice. As a retired senior figure in the Courts Service put it:

[I]f I had a concern or worry about a judge I had no one to go to. ... I could go to the president, but the president isn't a manager in the sense that every judge is independent ... A lot of people think that presidents can discipline but they can't. ${ }^{2}$

The only formal mechanism for judicial discipline is the impeachment process under Article 35.4.1 of the Constitution, which requires a vote by both houses of the Oireachtas (Parliament). This process has been threatened on two occasions in the last twenty years (see section C.III below) but has never been used. There are no powers to discipline judges for more trivial misbehavior that would not justify dismissal. ${ }^{3}$ For all other judges there are no disciplinary mechanisms whatsoever and the only option (short of impeachment) open to a Chief Justice or court President to change a judge's behavior is informal persuasion.

Beyond the core court-related functions the Irish judiciary is self-governing only in a limited respect, controlling only the Courts Service which since 1999 has managed court estate and non-judicial personnel. Key functions of administration, appointment, discipline and training and representation were traditionally managed through informal back-channel negotiations with the Government, were conducted exclusively by the executive, or simply did not exist (see Figure 2).

\footnotetext{
${ }^{2}$ Interview with the author.

${ }^{3}$ There are limited powers to investigate the behavior of District Court judges (but not to discipline them): Courts of Justice (District Court) Act 1946, § 21, Courts (Supplemental Provisions) Act 1961, §§ 10(4) \& 36(2). Investigation may be done at the request of the Minister or by the Chief Justice or District Court President acting on their own initiative. The power applies only to the District Court and has been used very rarely. See RAYMOND BYRne ET AL, THE IRISH Legal SYSTem (2014), 189; Laura Cahillane, Ireland's System for Disciplining and Removing Judges 38 DUBLIN UNIVERSITY LAW JOURNAL 55 (2015).
} 
Figure 2: Changes to Irish judicial self-government over time

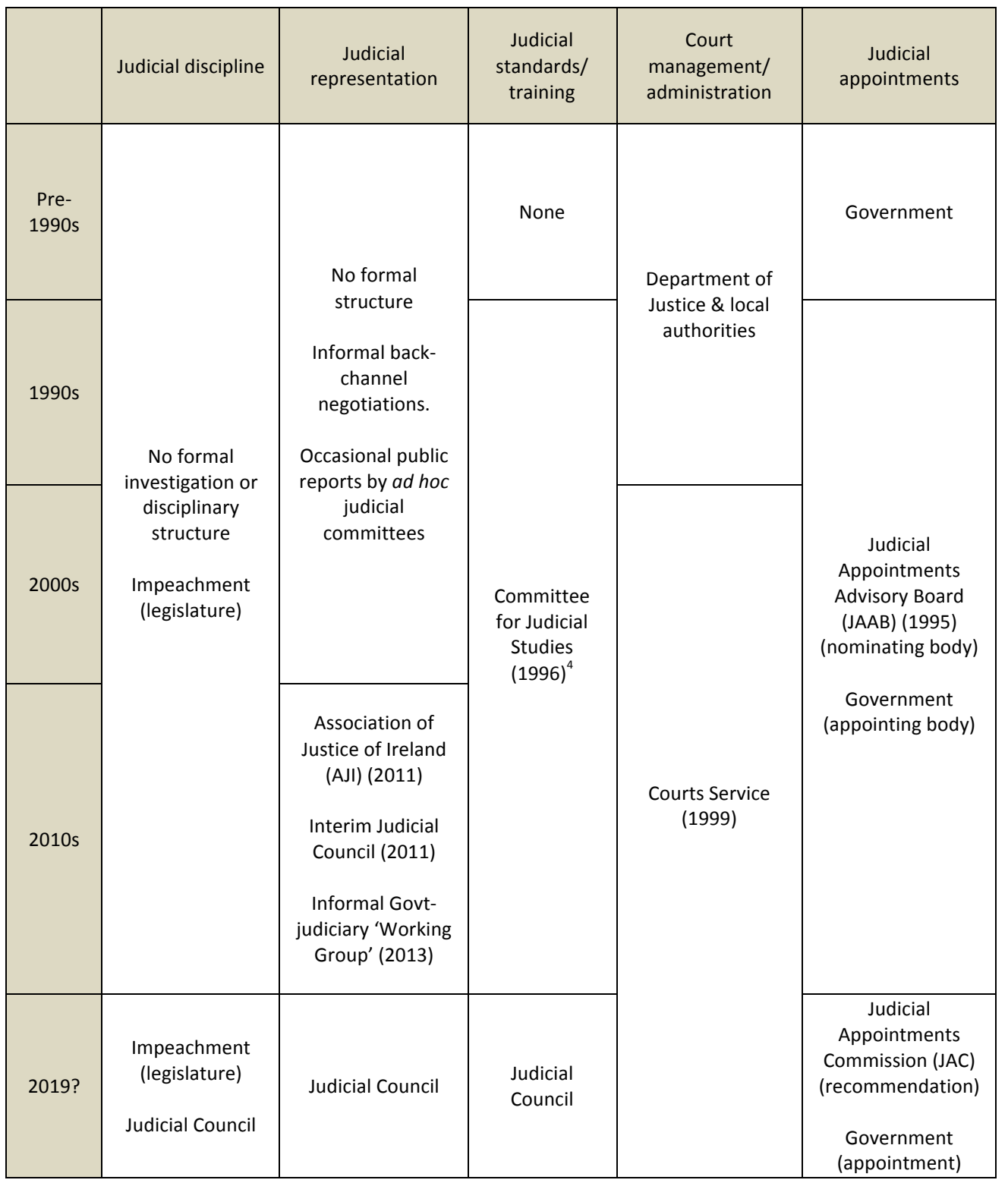

\footnotetext{
${ }^{4}$ Formerly the Judicial Studies Institute. It is currently envisaged that the Committee for Judicial Studies will continue operating under the auspices of the Judicial Council when it is created.
} 
Relations between the judiciary and the Government were historically conducted in one of two ways. Matters of high constitutional principle have been defined through the jurisprudence of the courts, which have created a very rigorous doctrine of the separation of powers. Administrative, technocratic and 'trade union'-type discussions between judges and were conducted completely out of public view, according to a model described by $\mathrm{O}^{\prime}$ Dowd as 'presidential'. ${ }^{5}$ Key figures on the judicial side were the Chief Justice and the court Presidents, and on the Government side were the Minister for Justice (as the line minister) and the Attorney General (as leader of the Bar). ${ }^{6}$ The common mechanism for communication to the Government was a letter from the Chief Justice to the government, sent through the Attorney General. ${ }^{7}$ For most of the history of the state these quiet informal mechanisms functioned well. Ireland is a small country and members of the legal and political elite would often be known personally to each other. Judges enjoyed considerable influence over the government behind the scenes and each side was able to respond flexibly and pragmatically to matters of joint concern. During the financial crisis of the last decade, however, these traditional channels of communication broke down, sometimes completely, and relations have not completely recovered.

Beyond the traditional core of judicial functions, the Courts Service is the only significant judge-led part of the justice system. Prior to its creation in 1999, court estate was managed by the Department of Justice and by local authorities. Court staff were part of the Department of Justice; although lines of responsibility between the Department and court staff were badly fragmented. These disparate responsibilities and staffing arrangements were all unified in a judge-led Courts Service created as a state agency in 1999. The core responsibilities of the Service are to

(a) manage the courts,

(b) provide support services for the judges,

(c) provide information on the courts system to the public,

(d) provide, manage and maintain court buildings, and

(e) provide facilities for users of the courts. ${ }^{8}$

\footnotetext{
${ }^{5}$ John O'Dowd, Speaking to power: mechanisms for judicial-executive dialogue in LAURA CAHILLANE ET AL (EDS), JUDGES, POLITICS AND THE IRISH CONSTITUTION 155 (2017).

${ }^{6}$ In Ireland the Attorney General is appointed by the Government as its chief legal advisor and is not a serving politician or a member of the Cabinet: see art. 30 of the Constitution of 1937.

${ }^{7}$ David Fennelly, Reluctant reformers? Formalizing judicial regulation in Ireland in REGULATING JUDGES: BEYOND INDEPENDENCE AND ACCOUNTABILITY (Richard Devlin \& Adam Dodek ed. 2016) at 222.
}

${ }^{8} \S 5$, Courts Service Act 1998. 
Day to day management of the Service is conducted by its Chief Executive and staff. The Chief Executive is recruited and appointed by a Board which is chaired by the Chief Justice and which contains a judicial majority. Two Chief Executives have served so far; both have been former civil servants. ${ }^{9}$ The Board is also responsible for strategic planning and policy. It comprises 18 members, of which ten are judges: the Chief Justice (as chair), the President of each court and a second judge from each court elected by the members of that court. ${ }^{10}$ The Service is an agency of the Department of Justice and its budget is secured as part of the Department of Justice vote in the Oireachtas. The Service is accountable to the Oireachtas through its Chief Executive and, politically, through the Minister for Justice. The separation of powers culture in Ireland is such that it is considered inappropriate for judges to appear before parliamentary committees, and the lines of accountability for the new Service were carefully drawn so that judges were protected from having to account for their judicial functions. ${ }^{11}$ Oireachtas committees may summon the Chief Executive to give evidence, but they may not require him to account for judicial functions or the conduct of court proceedings. In the event of a disagreement about whether a request relates to a judicial function or to court proceedings, the matter may be remitted to the High Court for a binding determination. ${ }^{12}$

Through its responsibility to provide support services to the judiciary, the Courts Service also provides administrative services to court rules committees (which as a core judicial function sit outside the organization), and to a number of standing committees on issues such as court estate and family law. The Service has taken a creative approach to its responsibility to provide services and information, such as its sentencing information initiative. The Courts Service Act 1998 also gave the Courts Service an advisory role in relation to court policy. This has given judges an input into policy for the first time, and led, for example, to the creation of a Commercial Court. At an unofficial level judges have had input into some courts-related draft legislation. ${ }^{13}$ Also supported by the Courts Service is the Committee for Judicial Studies. Established by then Chief Justice Liam Hamilton in 1996, this Committee is responsible for education and training for the judiciary. ${ }^{14}$ The

\footnotetext{
${ }^{9}$ The first Chief Exectuve, PJ Fitzpatrick, was a former senior health service executive, and the second, Brendan Ryan worked for most of his career in court administration. Note that I am using 'civil servant' in its generally understood sense. There is a technical distinction between 'civil servants' and 'public servants' in Irish public administration but it is not relevant to this discussion.

${ }^{10} \S 11$ of the 1998 Act, ibid, (as amended by $\S 57$, Court of Appeal Act 2014).

${ }^{11}$ See Robert Hazell and Patrick O'Brien, Meaningful Dialogue: Judicial Engagement with Parliamentary Committees at Westminster (2016) PUBLIC LAW 54, 58.

${ }^{12} \S 21$ of the 1998 Act.

${ }^{13}$ Information from interviews. The advisory power is contained in § 6(f) of the 1998 Act. For an example of innovation on the part of the Service see http://www.irishsentencing.ie [last accessed 15 September 2017].

${ }^{14}$ The Committee was formerly known as the Judicial Studies Institute and was established to fulfil a very limited mandate to train judges provided for in the Courts and Court Officers Act 1995 ( $\S \S 21$ and 48 of the Act).
} 
Committee is funded by the Minister for Justice ${ }^{15}$ with administrative support provided by the Courts Service. The Committee provides training courses and manuals for the judiciary, as well as a specialist journal. However, the Committee has 'extremely limited financial resources and is accordingly unable to provide the type of continuing training and education that is common in other jurisdictions' ${ }^{16}$ Other than for newly appointed judges, training is not mandatory. ${ }^{17}$

The functions of the Courts Service do not extend to representation of the judiciary. Nor does the Service have any power in relation to judicial discipline (discussed further below). There is currently, following a serious rupture in relations between the government and the judiciary in 2011, a non-statutory interim Judicial Council which aims to represent the judiciary and also providing a structure for managing judicial standards, education and ethical issues. There is also the Association of Judges of Ireland (AJI), which was established to provide representation for judges to the government and in public debate. The Council and the AJl were established on the same day. Whereas the interim council comprised the entire judiciary, the AJl attracted membership from approximately $80 \%$ of judges. After an initial flurry of activism from the AJl, the more militant of the two bodies, and some initial difficulties balancing the organizations (discussed below), it appears that the interim Judicial Council has become the more important body for organizing and representing the judiciary.

Legislation currently before the Oireachtas will make significant changes to current arrangements. The Judicial Council Bill 2017 will create a Judicial Council that will give judges control over their own training, organization, representation and discipline. The Council will be chaired by the Chief Justice and every judge will automatically become a member. The remit of the proposed Council over judicial discipline is central to the proposal. A committee of the Council (the Judicial Conduct Committee) will be empowered to accept complaints and if necessary to refer them to a panel comprising a mixture of judges and laypeople for investigation. ${ }^{18}$ Where appropriate, the Committee may issue reprimands and/or direct judges to undertake further training. In serious cases, the Committee may refer a case to the Minister for Justice with a recommendation to initiate the procedure for impeachment under Article 35.4.1 of the Constitution. As in the case of the Courts Service, the Council will be made accountable to the Oireachtas through its

\footnotetext{
${ }^{15} \S 48$ of the 1995 Act.

${ }^{16}$ As the website for the Association of Judges of Ireland puts it: https://aji.ie/supports/judicial-education/ [last accessed 15 September 2017].

${ }^{17} \S 19$ of the 1995 Act.

${ }^{18}$ Chapter 5 of the Judicial Council Bill 2017.
} 
Secretary, rather than a judge, and the Secretary may not be required to account for court proceedings or the exercise by judges of their judicial functions. ${ }^{19}$

Judicial appointments were historically an exclusively political domain in Ireland. Under the Constitution judges are formally appointed by the President of Ireland on the recommendation of the Government. The choice of judges to appoint is thus made by the Government. ${ }^{20}$ In practice, the choice was controlled by the Taoiseach, Minister for Justice and Attorney General, who would discuss the matter in advance and present the Cabinet with a nomination that had already been agreed. ${ }^{21}$ As a result, judicial appointments were partly a facet of party political patronage exercised by the government; especially at District Court level, where it was not unheard of for prospective candidates to lobby for positions. The relationship between politics and appointment is complex and subtle, however. Political affiliations appear to become less important above the District Court, and especially for senior appointments. Carroll-MacNeill reports that judges, politicians and commentators generally accepted that judges were and are primarily appointed on merit. It is difficult to be definitive, but it appears that political connections with the governing party might be helpful to a prospective candidate as a tiebreaker with other equally qualified applicants, but are not otherwise essential or decisive. ${ }^{22}$

Since 1994, the Government's discretion over judicial appointments has been constrained, although only slightly. Following a political controversy, the Judicial Appointments Advisory Board (JAAB) was established to recommend candidates for appointment by the Government. The Board is chaired by the Chief Justice and the President of each court is a member ex officio, giving judges five positions and so significant influence. The Attorney General is also an ex officio member of the Board and there are representatives of the Bar Council and the Law Society, ${ }^{23}$ giving the legal profession a significant majority (eight) on the eleven-member Board. ${ }^{24}$ The role of the Board is, however, very limited. When the Board conducts a selection exercise it is required, firstly, to submit the name of each

\footnotetext{
${ }^{19} \S 28$ of the Judicial Council Bill 2017.

${ }^{20}$ Art. 35.1 read with art. 13.9 and art. 13.11 of the Constitution of 1937.

${ }^{21}$ Jennifer Carroll MacNeill, The Politics of Judicial Selection in Ireland (2016), 105-6. See also Paul Bartholomew, THE IRISH JUDICIARY (1971), 31-33.

${ }^{22}$ CARRoll MACNEILL, ibid, at 107 and 137-8. Where there is a coalition government, there has generally a loose agreement about how decisions about judicial appointments should be distributed. Carroll MacNeill notes also that political affiliations have become weaker in the general population in recent years, so might be expected to play a less prominent role in contemporary appointments if candidates have correspondingly looser political connections (at 107-8).

${ }^{23}$ The Bar Council is the professional organisation for barristers and the Law Society the professional body for solicitors in Ireland.

${ }^{24} \S 13(2)$ of the 1995 Act, as amended by $\S 12(b)$ of the 2014 Act.
} 
person who has applied for the vacancy to the Minister for Justice and, secondly, to recommend to the Minister at least seven candidates for the vacancy. ${ }^{25}$ The Government is not required to appoint from the list submitted by the $\mathrm{JAAB}^{26}$ and as a result its discretion over judicial appointments has been left almost completely intact. An early political convention developed to the effect that the Government should, absent some compelling reason, select from the within the JAAB list. This convention was, however, rendered irrelevant by a policy decision by the Board in the early 2000s to begin recommending all candidates it considered suitable. This decision, apparently reached out of concern that to do more would impose unconstitutional constraints on the Government's freedom to appoint judges, limited the JAAB's role to that of a screening body. ${ }^{27}$ The Government will not appoint someone who the Board has declined as unsuitable, although in 1998 the Board threatened to resign en masse when the Government proposed to appoint a candidate it regarded as unsuitable. ${ }^{28}$ There is some indication that the Board reversed its policy somewhat in recent years, recommending fewer candidates ${ }^{29}$ and for its Court of Appeal exercise in 2016 it reported to the Government that there was no candidate it could recommend. ${ }^{30}$ The JAAB has no role in the promotion of serving judges, with the result that such promotions automatically entail that the Government ignores any JAAB recommendation. The vast majority of Supreme Court appointments are of serving judges and so the JAAB has little or no influence over appointments to that court, which remain largely unregulated. ${ }^{31}$ Section 34 of the 1995 Act provides that the Government shall first have regard to serving judges when considering candidates for the office of Chief Justice or court President.

\footnotetext{
${ }^{25} \S 16(5)$ of the 1995 Act. CARRoLl MACNEILL, supra note 21, 113-6, gives an account of the processes within the Board, although she notes that its practices are opaque. It has the power to conduct interviews but has never done so, with the result that the process is entirely paper based, using an application form and CV. The practice is that the Chief Justice will open discussions on a candidate, followed by the other judges in order of seniority and with particular attention paid to the views of the President of the court to which the recruitment exercise relates and then the other members of the Board. Once a shortlist is created, the professional bodies are contacted to ensure that the recommended persons are of good professional standing. The Secretary of the Board then conveys its recommendations to the Minister.

${ }^{26} \S 16(6)$ of the 1995 Act requires only that the Government consider candidates recommended by the JAAB before others.

${ }^{27}$ CARroll MACNeILL, supra note $21,129$.

${ }^{28}$ David Gwynn Morgan, Selection of Superior Judges, 22 IRISH LAW TIMES 42 (2004).

${ }^{29}$ CARroll MACNeill, supra note 20, 98.

${ }^{30}$ See e.g. Mary Minihan, Ross unhappy at way Máire Whelan elevated to Court of Appeal, The Irish Times, Jun. 13 2017.

${ }^{31}$ CARRoll MACNeILL, supra note 21,100
} 
The Judicial Appointments Commission Bill 2017, currently before the Oireachtas, aims to reform the system by creating a Judicial Appointments Commission (JAC) modelled loosely on the organization of the same name in England and Wales. Unlike the JAAB, the proposed JAC will recommend only three names to the Government and there is a greater emphasis in the new Bill on the principles of merit and diversity in appointments. The JAC will also have greater lay representation than the JAAB, with a lay chair and six lay members and only three ex officio judicial members - the Chief Justice and the Presidents of the Court of Appeal and High Court - and only two on decision panels of the Commission. ${ }^{32}$ The result is that judges will have less influence in the new JAC system than they have under the JAAB. This has been a source of considerable disquiet amongst the judiciary. ${ }^{33}$ As with the Judicial Council Bill, accountability to the Oireachtas will be through the lay chair of the JAC and judges are protected from being made accountable for court proceedings or for the exercise of their judicial functions and the Bill also creates a new criminal offence of canvassing for judicial appointment or seeking to influence the process of the JAC. ${ }^{34}$ As in the case of the 1995 Act, the new Bill will require the Government only to 'first consider' the recommendations of the JAC before making an appointment. Formally, at least, the Government will retain an almost unconstrained discretion to appoint a candidate of their choice. It may be that practice and conventions emerge to give shape to this discretion, but given the experience of the JAAB this cannot be guaranteed. Indeed the passage of the Bill itself is not yet guaranteed: it has recently been heavily amended at Committee stage, much to the Government's dissatisfaction, and at time of writing (May 2018) the Government is proposing further extensive amendments. ${ }^{35}$

\section{Separation of Powers Doctrine}

Given the relative absence of judicial self-governance in Ireland, the most important landmarks in the development of judicial power have been legal and doctrinal rather than administrative. That the power of the courts has never become a matter of serious controversy in Ireland is, given the extensive power of the judiciary, remarkable. The 1937 Constitution enshrines a Supreme Court with a strong power of judicial review over legislation enacted by the Oireachtas. The judicial review power lay dormant for a long time after independence under both the 1922 and 1937 Constitutions. Judges and barristers had been educated under the British system, which places central importance on

\footnotetext{
${ }^{32} \S \S 12$ and 13 of the Judicial Appointments Commission Bill 2017 [hereinafter 'JAC Bill'].

${ }^{33}$ E.g. Fiach Kelly, Judges warned Varadkar Ross's reforms wouldn't work, The Irish Times, Aug. 182017 and Mary Minihan, Judicial reform plan a "deliberate kick in the teeth" for Chief Justice, The Irish Times, Jun. 272017.

${ }^{34} \S 25$ and $\S 64$, JAC Bill.
}

${ }^{35}$ E.g. Vivienne Clarke, Charlie Flanagan says judicial bill 'in a difficult place', The Irish Times, Mar. 262018. Author's note: I made a submission to the Committee stage of the Bill and some of the amendments I proposed formed part of an earlier version of the Bill. 
the sovereignty of Parliament and were slow to challenge politics and the legislature even though they were given the constitutional power to do so. ${ }^{36}$ It was not until the first group of judges who had been educated entirely in the independent Irish system began to reach the apex of the judiciary in the 1960s that this changed. The 1961 Supreme Court appointments of Cearbhall Ó Dálaigh and Brian Walsh, both strongly influenced by American jurisprudence, led to rapid development of the personal rights guarantees in the Constitution and transformed the Irish Supreme Court from a backwater in Irish life into one of the most powerful apex courts in the world. The new judges were anxious to break away from what they saw as the constraints of the older British constitutional model. They felt that they had been given license to do so by the Taoiseach, Seán Lemass, who told them privately on appointment that he wanted the Irish Supreme Court to be more like its American counterpart. ${ }^{37}$ This change in judicial outlook is perhaps the key moments in the development of the separation of powers in the Irish system. The seminal case of Ryan $v$. Attorney General, ${ }^{38}$ in which the courts asserted a power to read 'unenumerated' personal rights into Article 40.3 of the Constitution, led to two decades of ambitious judicial activism that reshaped the relationship between the individual and the state in areas like the rights of the criminal accused and rights to privacy and family life.

The legitimacy of this activism went largely unchallenged in politics, partly because many of the rights that were read into the Constitution were relatively uncontroversial civil and political rights, such as to bodily integrity or to privacy. The lack of controversy may also be due to another feature of the Irish constitutional system. The central ideology of the Irish Constitution is the idea of popular sovereignty. The 1937 Constitution was approved by the people in a referendum and may only be amended by referendum. Since the 1970s, referendums have been held frequently and many referendums arise as a consequence of - or an attempt to reverse - decisions of the Supreme Court. The practice of using referendums as a backstop to prevent the courts running too far ahead of politics has made judicial activism less problematic from a democratic perspective than it has been in, for example, the United States. Nonetheless the Supreme Court over time became gradually more uncomfortable with its own activism - and particularly the Ryan doctrine and changes of Supreme Court personnel led to a 'closing of the door' to new unenumerated rights. A more legally conservative reading of the Constitution became dominant, associated particularly with the appointment in 2000 of Adrian Hardiman who became an influential classical liberal voice on the Court. The contemporary Supreme Court takes a more literal and less expansive reading of the Constitution, and is often more deferential to the elected branches of government than its predecessors of the 1960s and

\footnotetext{
${ }^{36}$ Ronan Keane, Judges as Lawmakers: The Irish Experience, 4 RADHARC 81 (2003), 88.

${ }^{37}$ RuAdHÁn MACCORMAIC, THe SUPREME COURT (2016), 78.

${ }^{38}$ Ryan v. Attorney General [1965] IR 294
} 
1970s. ${ }^{39}$ This step back from rights-based activism represents a further significant change to the separation of powers; albeit one initiated by judges themselves.

Judges have also been willing to defend their own independence through their judgments. A highly robust doctrine of the separation of powers has been used to prevent encroachment by the political branches on core judicial functions like sentencing. This has been respected by politicians even where it was controversial, as in the Abbeylara decision in which the Supreme Court held that the finding of fact was an inherently judicial function and so that Oireachtas committees had no power to make findings of fact in their inquiries - a significant limitation on what is a common investigative power in other parliaments. ${ }^{40}$ Finally, the courts have been willing to defend the role of the people and the democratic aspect of the Constitution, as in the Crotty decision, in which the Supreme Court held that any major amendments to EU treaties must be put to the people in a referendum. ${ }^{41}$

\section{Public confidence in the judiciary in Ireland}

The Irish judiciary have in traditionally enjoyed robust public confidence. Longitudinal data on public confidence in the judiciary are hard to come by, as this is not routinely the subject of public surveys in Ireland, but available data suggests a positive view of the judiciary. Ireland is consistently ranked in the top ten countries in the world for perceptions of judicial independence by the World Economic Forum Global Competiveness Survey. ${ }^{42}$ These figures appear to have been unchanged by the economic crisis or the difficult politics that surrounded judicial salaries from 2009 onwards. The OECD recorded figures for public confidence in the judiciary at $65 \%$ in 2007 and $67 \%$ in $2014 .^{43}$ Eurobarometer figures for public perceptions of judicial independence in Ireland were $75 \%$ in 2016 and $74 \%$ in $2017 .^{44}$

\footnotetext{
${ }^{39}$ See e.g. the judgment of Mr. Justice Hardiman in Sinnott v. Minister for Education [2001] 2 IR 545. This judgment is quoted approvingly by Ronan Keane, supra note 36 , then recently retired as Chief Justice, at page 95.

${ }^{40}$ Maquire v. Ardagh [2001] 1 IR 385. A referendum to reverse this decision was held at the same time as the referendum on judges' pay but was rejected by the people.

${ }^{41}$ Crotty v. An Taoiseach [1987] IR 713. See also McKenna v. An Taoiseach (no. 2) [1995] 2 IR 10 which significantly restricted the freedom of the Government to spend public money in the context of referendum campaigns.

${ }^{42}$ Figures from World Economic Survey Global Competitiveness Survey produced between 2000 and 2017 score Ireland at 6.3 or 6.4 out of a possible 7 , and put the country between $3^{\text {rd }}$ and $8^{\text {th }}$ in the world on this measure.

43 OECD, Government at a Glance 2015 (2015), Chapter 12: Serving Citizens. Available at: https://stats.oecd.org/Index.aspx?DataSetCode=GOV_2015 [last accessed Sept. 15 2017].

${ }^{44}$ Flash Eurobarometer 435 (February 2016) and 447 (January 2017), Perceived independence of the national justice systems in the EU among the general public: http://ec.europa.eu/commfrontoffice/publicopinion/index .cfm/ResultDoc/download/DocumentKy/77652 [last accessed 15 September 2017].
} 
Figure 3: Trust in justice \& political parties, with life satisfaction (Eurobarometer 20002017)

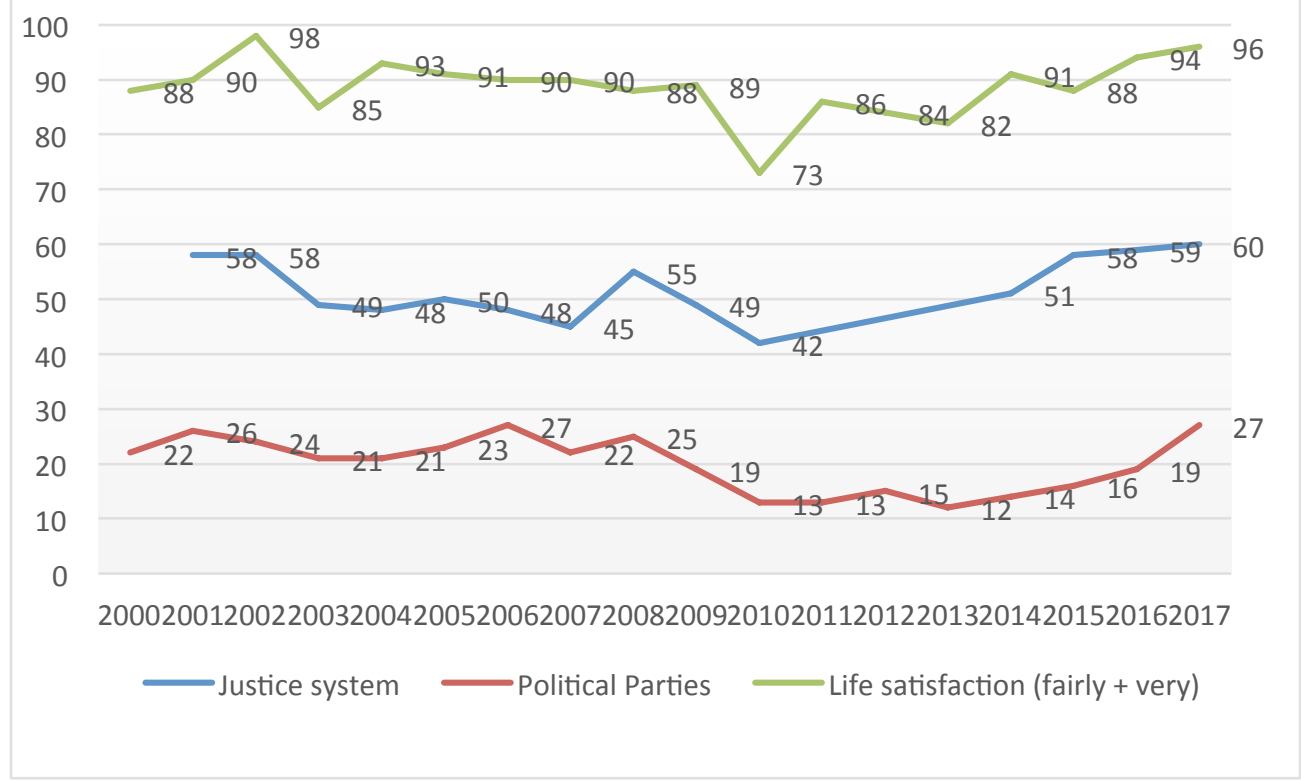

Irish statistics on trust in the justice system are weaker (see Figure 3$)^{45}$ but significantly outperform equivalent results for politics. Taking these statistics together, we can hypothesize that trust in the judiciary and judicial independence have remained reasonably robust, but there was a noticeable decline in trust in the justice system between 2010 and 2014 followed by a recovery. During the same period there was an acrimonious public debate in Ireland about whether judges' salaries should be reduced (discussed in Part D below). The decline in trust in judges at this time may indicate that the difficult politics associated with the salary issue damaged the system. There is anecdotal that some judges were heckled by the general public - and on one occasion by a juror - about their salaries. ${ }^{46}$ Note, however, that this was a period of extreme economic downturn in Ireland.

\footnotetext{
${ }^{45}$ Figure 3 uses the figures for 'tend to trust' in response to survey questions on 'justice/the legal system' and 'political parties' from Eurobarometer surveys from 2000-2017. The third figure adds together the 'very satisfied' and 'fairly satisfied' responses to the survey question 'One the whole are you very satisfied, fairly satisfied, not very satisfied or not at all satisfied with the life you lead?' Data taken from http://ec.europa.eu/commfrontoffice/ publicopinion/index.cfm/General/index. [last accessed Sept. 15 2017.]
}

${ }^{46}$ See MACCORMAIC, supra note 37 , at 368. 
Self-reported life satisfaction also declined steeply during the same period (see Figure 3). A similar decline appears to have occurred in 2002-2003, coinciding with a similar decline in the life satisfaction figures and a (less severe) economic downturn. Trust in institutions appears to be significantly correlated with factors that are not connected to the performance of those institutions, such as life satisfaction and education. ${ }^{47}$ The Eurobarometer figures for perceptions of judicial independence are also significantly influenced by levels of education. ${ }^{48}$

Anecdotal evidence suggests that general public awareness of self-governing judicial institutions in Ireland is very low, and it seems unlikely that the role that they play has any significant effect on public trust in the judiciary. This is especially the case given the effect that external factors such as education and life satisfaction appear to have on trust in this context. However, the creation of the Courts Service has allowed the judiciary to improve the public image of the courts through improved facilities and have increased the transparency of the courts system through the Courts Service website and annual reports. It is possible that these changes have played a small role in enhancing public trust and improving the legitimacy of judges and the courts.

\section{The politics of judicial reform}

Literature on judicial independence emphasizes the importance of cultural factors over and above formal rules protecting the function and status of judges or creating elaborate systems for judicial self-governance. Not only is de facto judicial independence more important to good governance than de jure judicial independence, but there is not always a direct connection between the two. ${ }^{49}$ As the 'least dangerous branch', ${ }^{50}$ judges are dependent on the political branches of government for the 'purse' and the 'sword': for provision of resources and enforcement of judgments. The Irish system, as discussed in the last section, appears to bear this analysis out. Ireland has a robust de facto culture of

\footnotetext{
${ }^{47}$ See e.g. Steven Van de Walle \& John Raine Explaining Attitudes towards the Justice System in the UK and Europe (2008) MINISTRY OF JUSTICE RESEARCH SERIES 9/08, 30.

${ }^{48}$ See Flash Eurobarometer 447, supra note $67.63 \%$ of those who finished school before the age of 15 rated the independence of Irish judges as good or higher, whereas $79 \%$ of those who finished at above the age of 20 did so.

${ }^{49}$ There is a significant literature on the relationship between de facto and de jure independence. See eg William Landes and Richard Posner, The Independence Judiciary in an Interest-Group Perspective 18 JoURNAL OF LAW AND EConomics 875 (1975). Charles Cameron, Judicial Independence: How Can You Tell It When You see It? And Who Cares? in JUdICIAL INDEPENDENCE AT THE CROSSROADS: AN INTERDISCIPLINARY APPROACH (Stephen Burbank \& Barry Friedman ed. 2002); Yash Vyas, The Independence of the Judiciary: A Third World Perspective 11 THIRD WORLD LEGAL STUDIES 127 (1992); Stefan Voigt \& Bernd Hayo, Explaining De Facto Judicial Independence 28 INTERNATIONAL ReVIeW of LaW AND EConomics 269 (2007); David Kosar, Perils of Judicial Self-Government in Transitional Societies (2016); Gee et al, supra note 1, chapter 2.

${ }^{50}$ AleXANDer Bickel, The LeAst Dangerous BRanch (1986).
} 
judicial independence despite its comparative lack of structures for judicial self-governance in areas such as internal discipline and appointments. The system has historically depended on good relations between politics and the judiciary, and a culture of restraint on both sides, to function. However, Ireland also shows the limitations of this culture when it comes to reforming and improving the systems for managing judges and the court system. Reforms have been episodic, reactive - to controversy, or to technocratic concerns - and highly responsive to the personal projects of senior judges and politicians. As the examples in this section show, reforms to the judicial system depend on goodwill and investment from both politicians and judges to succeed and arguably this has been forthcoming in only one case: the establishment of the Courts Service.

\section{Judge led reform: The Courts Service}

The process of creating the Courts Service began with a Working Group on a Courts Commission chaired by the Supreme Court judge Susan Denham. The emphasis in the Commission's 1996 report was on efficiency, coherence and coordination. It focused on improving the 'client' experience in the light of massive increases in the case load and cost of the court system in the previous decade, the fragmentation of administrative structures, and the generally poor condition of the court estate. ${ }^{51}$ The courts were the 'poor relation' in the Department of Justice's responsibilities and lines of authority within the civil service were sometimes chaotic. The benefit to judges was clear: a coherent and service-oriented courts system that could engage in more strategic planning and which was responsive to its users and those working in it. Not all judges were convinced of the merit of the proposals. Some were particularly concerned about their independence. The old system had been unsatisfactory in many ways but the Department had been scrupulous about never encroaching upon judicial functions. Ms. Justice Denham had to work hard to convince judges that the change was not a threat. The new Service won judicial support in a number of ways. As the senior figure in the Service interviewed noted, the presence of judicial board members elected by their peers reassured rank and file judges that their voices were heard. Subcommittees and ad hoc committees supported by the resources of the Service in areas such as finance, family law and building gave judges a sense of ownership of the system. And over time improvements to the courts and court administration provided physical evidence that the new system was working.

The Courts Service proposal also offered a significant benefit to politicians: it depoliticized the process of improving the court estate, which required politically sensitive decisions about which local courts should be closed. 'They transferred that function from the minister to us, the government did and mainly because the minister could never do it. ${ }^{, 52}$

\footnotetext{
51 Working Group on a Courts Commission: First Report (April 1996), available at http://www.courts.ie/Courts.ie/Library3.nsf/(WebFiles)/E33B888C196A85A980256DA6003459DA/\$FILE/courts1. pdf [last accessed 15 September 2017].

${ }^{52}$ Interview with the author
} 
Part of the reason for the decrepit state of much of the courts system was the notoriously local focus of Irish politics, which made closing underused local courts difficult. Court infrastructure and court buildings were generally in a state of serious disrepair, but parliamentarians would lobby furiously to prevent closure in their area. Putting these decisions in the hands of the judiciary allowed ministers to present unpopular decisions as the responsibility of someone else. This came with some cost to democracy - court policy was immunized from the political lobbying that characterizes most of Irish politics - but lines of accountability for the Service through the Minister for Justice and the parliamentary committee system remained intact.

The Courts Service is a success story. It rationalized and improved the court estate, closing many of the more unsuitable buildings. It introduced computerization for the first time (prior to 1999 court administration was paper-based). The judiciary has benefitted from their control over courts' budgets and appear to have used this control to improve the performance of the court system significantly; for example, to change the court fee structure to increase the charges for commercially valuable court applications (such as licenses to sell alcohol). Long-term bickering over facilities between local judges, in particular, and the Department of Justice largely came to an end. The establishment of the Service was primarily a judge-led project, but it benefitted significantly from the goodwill of politicians, who saw clear political advantages to the politicization of a major area of public service provision. It benefitted also from the fact that it was set up during an unprecedented economic boom in Ireland. With access to capital to spend on infrastructure the new Service was able to achieve a great deal in a short time. Relations between judges and the government were severely tested when money became tight a decade later (discussed in Part II).

\section{Reform through crisis: the politics of judicial appointments}

Judicial appointments formed the first part of the post-1990 wave of reforms of justice administration in Ireland. The JAAB reform was not, however, a carefully thought out technocratic or principled reform but rather a back-of-the-envelope response driven primarily by a tussle over political patronage at the top of Government. In 1994 the Taoiseach (prime minister) and leader of the Fianna Fáil party, Albert Reynolds, sought to appoint the serving Attorney General, Harry Whelehan, as President of the High Court. In doing so he incensed his coalition partners, the Tánaiste (deputy prime minister) Dick Spring and the Labour Party who felt (based on prior coalition practice) that it was their turn to make a judicial appointment. ${ }^{53}$ The Labour Party was also opposed to Whelehan personally, as they regarded him as a conservative Catholic damaged by his association

\footnotetext{
${ }^{53}$ CARROLL MACNEILL, supra note $21,67$.
} 
with the notorious $X$ Case two years earlier. ${ }^{54}$ Matters were made worse by allegations that Whelehan had mishandled the extradition of a priest accused of abusing a child. Reynolds' proceeded in spite of the objections, but his failure to back down brought the coalition Government to the point of collapse and the parties went into crisis negotiations. One outcome of these was an agreement to create an independent system to manage judicial appointments. In the event the deal failed - the government collapsed anyway. Whelehan resigned a day after that, having been in office for only six days. ${ }^{55}$

The policy reform to judicial appointments remained in place but its political raison d'être had been the preservation of the coalition government. Without this justification it was a political orphan. Nowhere in the Oireachtas (not even in the Labour Party) ${ }^{56}$ was there any appetite for placing meaningful constraints on the discretion of the Government over judicial appointments; widely regarded as a useful and essentially harmless piece of political patronage. Even Brian Cowen, the Fianna Fáil politician who had negotiated the deal, described the reforms as a 'charade' that was being continued only to spare the Labour Party (who had gone on to join a new coalition) the embarrassment of reversing their position.

I was one of the authors of the principle if not the detail of the Bill. The Bill has been put forward as a proper aspect of judicial reform but it has nothing to do with such reform. ... Any provisional agreement reached on this matter when I was a member of Government has nothing to do with judicial reform or efficacy of the courts system. ${ }^{57}$

The JAAB process as enacted in the Courts and Court Officers Act 1995 (as discussed above) left the Government's discretion almost entirely intact. The declared aim of the 1995 Act was not to introduce a form of judicial self-government - though it gave judges formal involvement in the appointments process for the first time - but to make appointments more independent from politics. The failure of the reform can be traced to the lack of political ownership of the proposals. ${ }^{58}$ The rationale for the reform was not to improve the governance of the judiciary, but to fix a political crisis. In the absence of that crisis it was - for politicians at least - a solution that lacked a problem.

\footnotetext{
${ }^{54}$ In 1992 Whelehan obtained an order from the High Court to prevent a suicidal 14-year old rape victim leaving the country for the purposes of an abortion. Attorney General v. X [1992] IESC 1, [1992] 1 IR 1 was successfully appealed to the Supreme Court and focused international attention on Ireland's highly restrictive abortion laws.

${ }^{55}$ MACCORMAIC, supra note 37,306 . The events also created some serious breaches of the separation of powers. Reynolds publicly criticized Whelehan and expressed regret at his appointment on the floor of the Dáil, and privately asked him to resign twice before the Government collapsed.

${ }^{56}$ CARROLL MACNEILL, supra note $21,73$.

${ }^{57}$ Dáil Éireann Deb., Nov. 29 1995, vol 459, no. 1, col 235-6.

${ }^{58}$ As CARROLL MACNEILL makes clear: supra, note $21,70-77$
} 
There matters rested for two decades, until the general election of 2016 produced another unwieldy coalition, this time between the Fine Gael party and a loose alliance of independent politicians. One of those who joined the new Government was Shane Ross, a former journalist and a long-standing critic of the system for appointing judges. ${ }^{59}$ As part of the coalition agreement negotiated with Fine Gael he insisted on reforms to make appointments independent from politics and the judiciary, and has repeatedly blocked appointments of judges until a new system can be put in place. The proposed reforms were given additional urgency by a further, though less serious, political crisis that mirrored that of 1994. In June 2017, outgoing Taoiseach Enda Kenny appointed the serving Attorney General to the Court of Appeal in his last significant act in office. The decision came after the JAAB had reported that it was not in a position to recommend anyone for the vacancy, but it was made despite the fact that a number of High Court judges had expressed an interest in the vacant position to the Attorney General herself. ${ }^{60}$ The controversy around the appointment appears to have accelerated the publication of the draft JAC Bill several weeks later. Once again, reforms to judicial appointments in Ireland are being pushed forward as a result of coalition politics. The judiciary are fiercely resisting the new JAC. They are unhappy at its proposed lay (non-lawyer) chair and lay majority and have made their views known in public lectures and through letters to the Taoiseach and Minister for Justice. Lurking behind this concern over lay membership appears, at least in part, to be a concern that the new JAC could be used as a vehicle for ideological screening of potential judges. A politician and senior barrister interviewed in summer 2017 expressed serious concern that the commission could be taken over by political activists, with the result that judges might (for example) face questions about their attitudes to abortion. ${ }^{61}$

\section{A judicial reform in want of a political crisis: the Judicial Council}

As already discussed, aspects of the Irish court and judicial system - especially the regulation of discipline and of judicial standards and education - stand out for the fact that they lack any form of organization or regulation. There is little power to compel a judge to engage in training, and the only formal disciplinary power is the power of the Oireachtas to impeach a judge for stated misbehavior. Ireland has been fortunate, given this absence of regulation, that its judiciary has generally been of a very high quality, but nonetheless judicial discipline has taken Ireland to the cusp of constitutional crisis twice in the past 20 years. Proposals to remedy it through the creation of a Judicial Council have been in

\footnotetext{
${ }^{59} \mathrm{He}$ is the co-author of SHANE ROSS \& NICK WEBB, THE UNTOUCHABLES: THE PEOPLE WHO HELPED WRECK IRELAND - AND ARE STILL RUNNING THE SHOW (2012), which characterized the system for judicial appointments as corrupt cronyism.

${ }^{60}$ Conor Gallagher, Several judges applied for vacant court position awarded to AG, The Irish Times, Jun. 152017.

${ }^{61}$ Conversation with the author, August 2017.
} 
circulation for almost as long, arising first in response to what became known as the Sheedy affair.

In October 1997 Philip Sheedy was convicted of dangerous driving causing death and sentenced to four years in prison. A year later a Supreme Court judge, Hugh O'Flaherty, met a member of Mr. Sheedy's family by chance and made an intervention in the case, asking the County Registrar for Dublin if it was possible for the case to be relisted for modification of sentence. O'Flaherty disputed that this was intended as an instruction but the Registrar appears to have interpreted it as such. A sequence of highly unusual and procedurally improper actions followed. The Registrar first invited Sheedy's solicitor to apply for the case to be relisted for modification of sentence. In November 1998, the case then came not before the original trial judge but before Judge Cyril Kelly. Kelly had no power to alter a sentence handed down by another judge, and made multiple procedural errors in the hearing itself. In particular, Kelly asked Sheedy's solicitor to have a medical report prepared on Sheedy so that it placed on file after the hearing, apparently to justify his decision to suspend the rest of the sentence. This would in effect falsify the record. ${ }^{62}$

The matter became a major public controversy in February 1999, when the Director of Public Prosecutions applied for judicial review of Judge Kelly's order. The Chief Justice, Liam Hamilton, investigated the matter. His report acknowledged that O'Flaherty's interest in the case was purely 'humanitarian' but concluded that his intervention in the matter was inappropriate, unwise and damaging to the administration of justice. Hamilton was even more critical of Kelly (by now a High Court judge) who had 'failed to conduct the case in a manner befitting a judge'. The report concluded:

In conclusion, I must, and do, emphasize that I, as Chief Justice, have no jurisdiction, whether under the provisions of the Constitution or any Act passed by the Oireachtas, to make any recommendations arising out of the facts in this case and, I do not, for this reason, propose to do so. ${ }^{63}$

Following a brief negotiation with the Government, both judges and the registrar resigned. The Government, grateful that a constitutional crisis had been avoided and cautious about judicial independence, secured the passage of special legislation to provide for pensions for all three. ${ }^{64}$ The Minister for Justice explained that the Government

\footnotetext{
${ }^{62}$ It is not clear if this second report was ever in fact put on the record. On the Sheedy affair, see John O'Dowd, The Sheedy Affair 3 CONTEMPORARY ISSUES IN IRISH LAW AND Politics (2000), 103. See also Fintan O'Toole, Unanswered questions about the Sheedy affair cannot be buried a second time, The Irish Times, Jun. 242000.

${ }^{63}$ Extracted in BYRNE ET AL, supra note 3, 186.

${ }^{64}$ Shortly afterwards the Oireachtas (legislature) enacted special legislation to provide for pensions for O'Flaherty, Kelly and the registrar: Courts (Supplemental Provisions) (Amendment) Act 1999.
} 
... took the view that, from the information available, the errors of judgments by three individuals, ... were quite serious but took into account that all three had taken the honorable course by resigning and had collectively helped to avert a difficult if not unprecedented position, from a constitutional standpoint. ${ }^{65}$

The Sheedy Affair led directly to proposals for reform. The Department of Justice proposed the creation of a Judicial Council to manage judicial discipline. This proposal had been foreshadowed several years earlier in a report by the Constitutional Review Group, which recommended that the Constitution should be amended to create a judge led Judicial Council that would be responsible for judicial discipline ${ }^{66}$ This report was accepted by the All-Party Oireachtas Committee on the Constitution in $1999 .^{67}$ The later judge-led Report of the Committee on Judicial Conduct and Ethics (2001) recommended that a Judicial Council with a broader remit for judicial conduct and ethics, for judicial studies and publications and for judicial pay and conditions. All judges would be members of this council and it would be led by the Chief Justice and heads of each court. This proposal would have required a referendum as it was constructed in such a way that an amendment to Article 35 of the Constitution was required. The Government accepted the recommendations and referendum legislation was prepared, but the amendment was withdrawn as opposition parties disagreed with some elements of the package.$^{68}$ The proposal ran out of steam and was not progressed.

A more serious case arose several years later. A Circuit Court Judge, Brian Curtin, was charged with possession of child pornography in 2002 but acquitted on a technicality in 2004 when it transpired that the key evidence against him - his personal computer - had been seized pursuant to an invalid search warrant. The result was that Curtin appeared to be guilty of a child sex offence but could not be convicted. The Oireachtas therefore began to put in place a process for impeaching him. As this had never been done before much of the process had to be created from scratch. A special joint committee of the Oireachtas was created for the purpose of examining the evidence against Curtin. Special legislation had to be enacted in order to give Oireachtas staff and Committee members immunity from prosecution in respect of handling the criminal material, and further legislation was required to compel Curtin to testify. ${ }^{69}$ Curtin resisted and delayed the process as much as

\footnotetext{
${ }^{65}$ Dáil Éireann Deb., vol 504, no. 2, 5 May 1999.

${ }^{66}$ Report of the Constitutional Review Group, April 1995. Available at http://archive.constitution.ie/constitutionalreviews/crg.asp [last accessed 15 September 2017].

${ }^{67}$ See BYRNE, ET AL, supra note 3, 188.

${ }^{68}$ BYRNE ET al, ibid, 191.

69 Amendment to $\S 3$ of the Committees of the Houses of the Oireachtas (Compellability, Privileges and Immunities of Witnesses) Act 1997.
} 
he could. When the Committee ordered Curtin to produce the computer, he challenged the request in the High Court and then the Supreme Court. The Supreme Court rejected his arguments, holding that power to impeach a judge in Article 35 of the Constitution included a power to investigation his fitness for office. ${ }^{70}$ Curtin then sought a further adjournment of the committee hearings on grounds of ill health. When this was not forthcoming he resigned from his position, having just served long enough in his post to qualify for his pension.

The Curtin case was the closest Ireland had come impeaching a judge, and the uncertain and improvised nature of the process only emphasized the potentially serious consequences of Ireland's lack of an infrastructure for judicial discipline. ${ }^{71}$ Once again, there was general support amongst politicians and judges for reform along the lines proposed in the 2001 report. ${ }^{72} \mathrm{~A}$ working group was established but progress on the matter remained extraordinarily slow. ${ }^{73}$ Draft bills were prepared in 2009 and 2010 but never progressed. A process involving the Government and the interim Judicial Council began in 2013 but produced a Bill only in 2017. This coincided with an unflattering report from the GRECO organization of the Council of Europe criticizing the delay in legislating for a Judicial Council, which appears to have provided some impetus for finalizing the proposals. ${ }^{74}$

There is no single reason for the extraordinary delay in implementing a Judicial Council proposal that has been supported across the judiciary and politics for 17 years. As with judicial appointments, however, part of the explanation is that the politics are not favorable. Even uncontroversial reforms to judicial administration lack sufficient political salience to make it onto the legislative agenda. They are simply not interesting or important enough to politicians. Irish politics in the past decade has revolved around highly controversial fiscal measures related to the economic collapse and EU/IMF bail-out of the

\footnotetext{
${ }^{70}$ Curtin v. Clerk of Dáil Éireann [2006] IESC 14, [2006] 2 IR 556.

${ }^{71}$ There have been other - fortunately isolated - incidents of misbehavior in recent years. Another judge, Heather Perrin, was convicted of deception in 2009 and resigned. At the trivial end of the spectrum, in 2011 an unidentified judge in a semi-naked and agitated state shouted and swore at a group of British tourists in a hotel who he felt were making too much noise, implicitly threatening them by mentioning that he had relatives who had fought in the old IRA against the British. The incident was reported to the courts but in the absence of formal disciplinary powers "[a]ll the senior judges could do was to sit down with the judge over a cup of tea and suggest that he take a rest." (MACCORMAIC, supra note 37, 382).

${ }^{72}$ Survey taken in 2007 by the Irish Council for Civil Liberties: Justice Matters: Independence, Accountability and the Irish Judiciary (2007), 72

${ }^{73}$ BYRNE ET AL, supra note 3, 193.

${ }^{74}$ Conor Gallagher, Report finds Ireland "unsatisfactory" in judicial independence, The Irish Times, Jun. 292017. See GRECO (Group of States against Corruption), Fourth Evaluation Round: Corruption prevention in respect of members of parliament, judges and prosecutors: Compliance Report: Ireland, Jun. 292017.
} 
country. Only very high profile political issues could get a hearing during the years of serious budgetary retrenchment. This situation may continue. A recent statement of Government legislative priorities refers to the Judicial Appointments Bill 2017 but not the Judicial Council Bill 2017. ${ }^{75}$

The political history of the Courts Service, judicial appointments and Judicial Council reforms appears to highlight the dependence of judicial reform in Ireland on politics and the political agenda. Where judicial reforms solve a problem for politicians they are willing to champion it. The Judicial Council reform, despite broad political support, has simply not been politically important enough to be enacted.

\section{Judicial independence, politics and personality: the financial crisis in Ireland and a crisis of relations}

\section{The referendum on judicial salaries}

Judicial independence in Ireland is robust. Notwithstanding the administrative limitations of judicial self-governance outlined above, and particularly the politicized nature of judicial appointments, there is no evidence of a party-political bias in the judgments of the Supreme Court. ${ }^{76}$ Elgie et al speculate that in the Irish system judicial appointments are a reward for service prior to appointment rather than an expectation of future behavior. They also point to the unusual nature of Irish politics, which has historically exhibited deep partisan divisions but only minimal ideological differences between the major parties, as a reason why partisanship might have limited effect on judicial decision-making. ${ }^{77}$ The strong culture of de facto judicial independence at the Irish bar is also important - especially given the absence of de jure accountability mechanisms. Judges, drawn from the legal professions in middle-age, will likely tend to share the cultural values of independence and objectivity of their peers who remain in practice, and given the relatively small size of the Irish legal profession will be anxious to maintain the esteem of colleagues on and off the bench. This could be a powerful control on the behavior of judges even after appointment. $^{78}$

75 Government Legislation Programme Autumn Session 2017, 19 September $2017 . \quad$ See http://www.taoiseach.gov.ie/eng/Taoiseach_and_Government/Government_Legislation_Programme/ [last accessed 22 September 2017].

${ }^{76}$ See Robert Elgie et al, The (not-so-surprising) non-partisanship of the Irish Supreme Court 33 Irish Political Studies 88 (2017). On the independence and accountability of the Irish judiciary generally, see Tanya Ward, Independence, Accountability and the Irish Judiciary (2008) Judicial Studies Institute Journal 1.

${ }^{77}$ Elgie et al, ibid, 105

${ }^{78}$ See Elgie et al, ibid, and David Gwynn-Morgan, Government and the Courts in GoVERNING IRELAND (Eoin O'Malley \& Muiris MacCarthaigh ed. 2011), 234. 
There is thus a very positive story to tell about de facto judicial independence in Ireland. Nonetheless the absence of machinery to manage or discipline judges has (as discussed above) taken Ireland close to constitutional crisis twice in the last twenty years. The longstanding proposals for a Judicial Council were directed particularly at this significant gap in judicial accountability mechanisms: the Council is intended to give the judiciary the power to police itself. The Judicial Council is also intended to provide an important coordinating and representative function for the judiciary. The absence of such representation was keenly felt in connection with the crisis in relations between the Government and the judiciary that between played out against the background of the financial crisis that engulfed Ireland from 2007 onwards. For most of its history, relations between the judiciary and the Government have been safe and unremarkable. The judiciary have generally been of very high quality, have kept out of politics, have exercised quiet influence over the Government over matters that were important to them. This changed dramatically around 2010-11, however. As a result of a financial crisis and the EU/IMF led bailout of the Irish exchequer, the salaries and benefits of all state employees were significantly reduced. The judiciary were exempted from these measures because of Article 35.5 of the Constitution, which provided that:

The remuneration of a judge shall not be reduced during his continuance in office.

The Attorney General advised the Government that this required judges to be exempt from the general cuts applied to other state employees. ${ }^{79}$ This special treatment of judges in a financial crisis was never going to be politically palatable and so initially a workaround was created. A process was established allowing judges to voluntarily forego a portion of their salary in line with the cuts to salaries of other public servants. Uptake of this scheme was, perhaps not surprisingly, quite slow and a source of negative public comment. ${ }^{80}$ (Although by January 2011 a significant majority - 111 out of 147 judges - had signed up to the scheme. ${ }^{81}$ ) The situation was not helped by the fact that Irish judges were amongst the highest paid in the world. Despite significant personal pressure from the Chief Justice and the senior judiciary, who feared the public and political reaction if judges were perceived to be refusing to make the same sacrifices as their fellow citizens, there remained a rump of judges who refused to engage with the voluntary scheme.

\footnotetext{
${ }^{79}$ It is arguable that this advice was overly conservative. In O'Byrne v. Minister of Finance [1959] IR 1, the Supreme Court had held that art. 35.5 did not exempt judges from the requirement to pay taxes and other charges that applied to all citizens. A levy applied to all state salaries might arguably have withstood constitutional scrutiny on the basis that it was not specifically directed at judges but at all public-sector employees. See Patrick O'Brien, 'Judicial Independence and the Irish Referendum on Judicial Pay', UK Constitutional Law Blog, Sept. 16 2011, available at http://ukconstitutionallaw.org/ [last accessed Sept. 15 2017].

${ }^{80} 19$ judges take voluntary pay cut, RTÉ News Jun. 19 2009: https://www.rte.ie/news/2009/0619/118642-judges/ [last accessed Sept. 15 2017].

${ }^{81}$ Voluntary levy paid by 111 judges, The Irish Times Jan. 182010.
} 
The new Government elected in February 2011 campaigned on a promise to change the Constitution in order to permit reductions to judges' pay. As all changes to the Irish Constitution must be approved by the people in a referendum, this would require a referendum. The new Justice Minister, Alan Shatter, had already tried to introduce a referendum bill while in opposition. ${ }^{82}$ Now in Government, he pushed the referendum and wholesale reforms to the courts and the legal profession with what O'Dowd dryly describes as his characteristic 'tenacity, trenchancy and vigor'. ${ }^{83}$ Shatter took no prisoners in politics. His brusque, tabloid-friendly style in selling his referendum proposal was nothing like the measured, respectful 'bedside manner' judges were used to. Many believed he was pursuing a vendetta against them. ${ }^{84}$ His proposals for reform to the legal professions were openly loathed by the Bar too. ${ }^{85}$ Significant resentment built up within the judiciary. Traditionally, Irish judges have observed a convention that they should not speak publicly on matters of political controversy. Conversations between judges and the Government about terms and conditions or the operation of the courts system were carried on firmly out of public view. The Attorney General would generally act as a postbox for letters and expressions of concern from the Chief Justice, as spokesperson for the judiciary, to the Government. For most of the history of the State this model had functioned well. Now, however, the mechanisms for communication within the judiciary and between the judiciary and the Government appeared to break down almost completely. ${ }^{86}$

A split developed within the judiciary between those who wished to continue this form of negotiation (including Chief Justice John Murray and his successor Susan Denham) and those (such as the Supreme Court judge Adrian Hardiman and the High Court judge Peter Kelly) who felt that quiet diplomacy had failed. This latter group wished to confront the Government and defend the position of the judges publicly. The way this split played out highlights the extent to which the Irish judiciary is not self-governing, and the way that individual judicial independence has hitherto over-shadowed corporate independence. In deciding a course of action, the divided judges of the Supreme Court could not agree whether to release a public statement. In the absence of unanimity, they could not even agree a process that would allow them to make the decision. ${ }^{87}$ Ultimately a compromise was reached. In July 2011, a memorandum was sent to the Government through the

\footnotetext{
${ }^{82}$ Twenty-Ninth Amendment to the Constitution Bill 2009.

83 John O'Dowd, Judges in whose cause? The Irish bench after the judges' pay referendum 48 IRISH JURIST N.S. 102 (2012), 108.

${ }^{84}$ MACCORMAIC, supra note $37,375$.

${ }^{85}$ Legal Services Regulation Bill 2011.

${ }^{86}$ O’Dowd, supra note 5, 162.

${ }^{87}$ MACCORMAIC, supra note $37,378$.
} 
Attorney General and subsequently released to the media through publication on the website of the Courts Service. The judges were at pains to point out in their Memorandum that they were not opposed to a pay cut as such, but expressed concerns about the wording of the referendum proposal itself, which they felt created a threat to judicial independence. They proposed instead that an independent body should be established to set judicial pay and conditions. Despite wanting for accuracy and proportion in places, ${ }^{88}$ the content of the Memorandum largely reflected the overwhelming view of the legal profession. ${ }^{89}$ The Memorandum was thus contestable, but relatively innocuous.

The judiciary could not, therefore, have anticipated the furious reaction of Shatter, who regarded the publication of the Memorandum on the website of the Courts Service as an unacceptable use of the resources of a state agency for political purposes. ${ }^{90} \mathrm{He}$ contacted the Chief Executive of the Courts Service to insist that it be removed. The incident revealed the fragility of the Courts Service's own independence. The Chief Executive was formally responsible only to the Board, with its judicial majority, but the political pressure from the Minister was considerable. The result was that, having been published on the Courts Service website at the request of the Chief Justice, the Memorandum was quickly removed at the insistent of the Minister for Justice. The Courts Service was revealed to be anything but a representative body for the judiciary. It subsequently emerged that the judiciary had sought - and been given - approval from the Attorney General to publish the Memorandum in this way but by that stage serious damage to relationships between the government and the judiciary had already been done. ${ }^{91}$

The referendum proposal passed by an overwhelming majority (nearly $80 \%$ ) in October 2011. The new Article 35.5 replaced the prior absolute restriction on reductions to judiciary salary with a conditional protection that reads, in relevant part:

\footnotetext{
${ }^{88}$ The suggestion that the proposed wording exposed Ireland to international reputational damage and possibly a case in the international courts was probably a rhetorical flourish too far: O'Dowd (2012), supra note 83, 122. The suggestion at the beginning of the Memorandum that judicial pay 'in these islands' had never been reduced since the Act of Settlement 1701 was woefully ignorant of legal history. Judicial pay for the UK (including Ireland) was significantly reduced in 1832 and judges took a pay cut of approximately 50\% upon Irish independence in 1922: BYRNE ET AL, supra note 3, 205. There was also a cut to the salaries of judges in England and Wales in 1931 in circumstances that bear remarkable similarity to the Irish experience of 2011. See ROBERT STEVENS, JUDICIAL INDEPENDENCE: THE VIEW FROM THE LORD CHANCELLOR'S OFFICE (OUP, 1993), 50-63.

${ }^{89}$ Legal opinion on the merits of the amendment tended towards the view that it was vague and badly worded, given that it lacked definitions of 'classes of persons' or the 'public interest' test set out. E.g. Ronan Keane, Judicial Independence: The best we can do? 29 Irish Law Times 191 (2011) and the other contributions to that special volume of the Irish Law Times.

${ }^{90}$ Minister disappointed memo still on court website, The Irish Times, Jul. 112011.

${ }^{91}$ Michael Brennan, AG gave judges go-ahead to publish memo on salary cuts, The Irish Independent, Jul. 112011.
} 
Where, before or after the enactment of this section, reductions have been or are made or are made by law to the remuneration of persons belonging to classes of persons whose remuneration is paid out of public money and such law states that those reductions are in the public interest, provision may also be made by law to make proportionate reductions to the remuneration of judges.

Following the amendment, salary cuts and related pension levies that had previously been applied to other public servants were extended to the judiciary.

The referendum campaign prompted a crisis in relations between the Government and the judiciary. From the perspective of the judiciary, they had been made the victims of a power play by a Government anxious to show its 'political virility' to the public. ${ }^{92}$ Privately judges lamented the impossible position they had been placed in, and many felt that the Government should simply have imposed the cuts under the old Article 35.5. 'No judge would have dared challenge that view in the current climate ... This was the worst of all worlds. ${ }^{93}$ Because of their constitutional position the judges could say very little in public to defend their position. The little they attempted to say - through the Memorandum was dismissed out of hand by the Government and removed from the website at the insistence of the Minister. The judges had no vehicle to express their views and, from the perspective of many, the presidential model of quiet relations had failed. The new Chief Justice, Susan Denham (appointed in July 2011) had a good working relationship with Shatter, but such was the personal animus many judges now had against Shatter, that this in itself became a source of criticism of the new Chief Justice from within the judiciary. ${ }^{94}$

\section{Judicial Council(s): rival power bases within the judiciary}

Following the referendum was the establishment two new judicial organizations were established at the national conference of the judiciary on 18 November 2011. The first was an 'interim Judicial Council', of which all judges would be members, created by the Chief Justice. This organization would perform functions in relation to judicial standards, ethics, education and representation and was explicitly created in anticipation of the long-awaited statutory Judicial Council. The second organization, the Association of Judges of Ireland (AJI), was created with the aim of giving judges a vehicle through which to speak on matters of importance. ${ }^{95}$ This organization, led by Peter Kelly, a High Court judge and inaugural President, was successful in attracting membership from around $80 \%$ of the

\footnotetext{
${ }^{92}$ Noel Whelan, More to power than making the right noises, The Irish Times, May 72011.

${ }^{93}$ Anonymous judge quoted in MACCORMAIC, supra note $37,368$.

${ }^{94}$ MACCORMAIC, supra note $37,380$.

${ }^{95}$ See the AJl's own explanation of its rationale at http://aji.ie/about-us/foundation/ [accessed Sept. 15 2017].
} 
judiciary and initially acted as something akin to a trade union. The functions of the two organizations clearly overlapped, although the AJl describes itself as acting in support of the work of the interim Council. ${ }^{96}$

Trust between the Government and the judiciary was at its lowest point in 2013, following further changes to pension provision and the unrelated decision of the Government not to reappoint three serving Irish members of European courts to their posts. In a break with prior practice, these returning European judges were not offered equivalent domestic judicial posts; something many judges felt was worse than anything else the Government had done so far. Matters were brought to a head by private remarks made by Peter Kelly to a gathering of business leaders in which he spoke of a complete breakdown in relations between the Government and the judges, and declared that the Government was dismantling judicial independence in Ireland 'brick by brick'. ${ }^{97}$ The remarks were leaked to the press and contemporaneous reports suggested that several judges were considering resignation. The AJl released a combative statement supporting Kelly and stating that '[a]II structures, both formal and informal, which existed for communication between these two branches of government have ceased. ${ }^{98}$ The Minister, Alan Shatter, released a statement of his own in response, accusing Kelly of exaggerating the situation and creating a misleading impression of a threat to judicial independence from the Government. ${ }^{99}$ Embarrassingly for Kelly and the AJI, Shatter was correct: they had indeed overstated matters. Relations between the two branches were hardly healthy, but - apparently unknown to Kelly - the Chief Justice, the Attorney General, and the Minister were still having private discussions in the traditional way. The creation of the AJl was a wellintentioned effort to channel some of the resentment of the activist faction of the judiciary and to institute clearer systems for communication with the Government and the public, but it had clearly backfired. The Association had not disrupted the traditional mechanisms for communication between the Government and the judiciary, but it had unintentionally created competing spheres of influence within the judiciary: the Chief Justice and the interim Judicial Council on the one side and the AJl on the other. The AJl appears to have been the response of the 'activist' faction of the judiciary, led by Kelly, Hardiman and the High Court President Nicholas Kearns amongst others, to the crisis of relations with the Government. But the 'diplomatic' faction of the judiciary, led by the Chief Justice, still apparently preferred the traditional sub rosa approach. The AJI was not simply a 'rank and file' movement. It counted some of the most senior judges in Ireland - although not the

\footnotetext{
${ }^{96}$ From the AJl's website, ibid.

${ }^{97}$ Dearbhail McDonald and Cormac McQuinn, Shatter sparks major judicial crisis, The Irish Independent, Apr. 16 2013.

${ }^{98}$ Judges' group back Judge Kelly's comments about political interference in judiciary, RTÉ News, Apr. 152013.

99 Alan Shatter criticizes High Court comments on pay, The Journal, Apr. 152013 [http://www.thejournal.ie/alanshatter-judicial-pay-8700890-Apr2013/ last accessed 15 September 2017]
} 
Chief Justice - amongst its membership. Kelly's remarks revealed a lack of communication between the groups. Part of the job of the Chief Justice now became to mediate between the Government and the more activist wing of the judiciary represented by the AJI. ${ }^{100}$

The crisis was defused by a carefully choreographed speech by the Chief Justice which was the product of talks between Denham, Kelly and the top level of Government. Denham explained that contacts with the Minister and the wider Government had continued through the crisis and announced the creation of a new Working Group to repair relations with the Government. This group would include the Chief Justice, Kelly (as president of the AJI) and representatives from each level of the court system. The Government would be represented by the Attorney General and the Government Secretary General (the country's top civil servant). Tellingly, the Working Group excluded the Minister for Justice, Alan Shatter. Under the new arrangements, coordinated through the Working Group, both sides appeared anxious to sue for peace. The judiciary quickly conceded a business-friendly extension to court terms ${ }^{101}$ and the Government held and won a referendum on the creation of a new Court of Appeal to sit between the High Court and Supreme Court (a long-held ambition of the Chief Justice). Referendums on low profile 'machinery of government' issues often create unforced political defeats for serving governments, so the fact that the Government was willing to hold the referendum at all indicates its commitment to fixing relations with the judges. ${ }^{102}$

The crisis and the way it was resolved serve to emphasize the importance of personality to the Irish system. One could conclude that the AJI owes its existence largely to a serious personality clash between Alan Shatter and the judiciary. Shatter's refusal to follow past practices for engaging with the judiciary gave some substance to their feelings of vulnerability during the economic crisis and eventually created a shadow of distrust over his every engagement with them. Judges had good reason to feel harshly treated by Shatter's high-handed approach, but in personalizing the matter they ignored the fact that the referendum had widespread support across Government and indeed widespread public support. They appear to have mistaken Shatter's aggressive political style for a genuine threat to their independence. On the available evidence such a threat was never in prospect. The politics of the 2011 referendum represented unfortunate own goals for both the Government and the judiciary, but it is only out of an abundance of caution on the Government's behalf that the referendum was held at all. Shatter departed from the Department of Justice in 2013 and his successors have been more emollient. In this calmer environment, the Working Group and the interim Judicial Council appear to have become the dominant vehicles for coordinating relations with the Government and within the

\footnotetext{
${ }^{100}$ O’Dowd (2017), supra note 5, 156.

${ }^{101}$ Ruadhán MacCormaic, High Courts to extent sitting into summer holidays, The Irish Times, Apr. 272013.

${ }^{102}$ O’Dowd (2017), supra note 5, 155.
} 
judiciary, with the AJl fading into the background. Judges have been angered by the proposed changes to judicial appointments in the JAC Bill 2017, and some have made personal public statements, but the AJl has reticent. It has released only one statement in relation to the 2017 Bill, and finished that statement by commenting that 'Having regard to its reluctance to become involved in public controversy, other than issuing this statement, neither the AJl nor its officers will be commenting further. ${ }^{, 103}$ To a Dublin legal journalist in September 2017, it appeared that the AJI 'isn't relied on too much' and that the interim Judicial Council was now the primary vehicle for lobbying and negotiations with the Government. ${ }^{104}$

\section{E. Conclusion}

Judicial independence and judicial self-governance depend on the support of politicians and a culture of mutual respect. The example of Ireland demonstrates this clearly. Judicial independence in Ireland is robust despite a comparatively significant role for politicians in appointments and the absence of structures for discipline and management. Conversely, a culture that depended on good informal relationships was vulnerable to disruption when, during the financial crisis, resources were strained and strong personalities became dominant. The development of court administration and judicial self-government processes in Ireland suggests a similar conclusion. The dire state of court administration and court buildings prior to 1999 owed much to the fact that politicians were uninterested in the former and unwilling to take responsibility for the latter. Politicians were only too willing to hand responsibility for closing local courts over to an independent and apolitical judicial branch, and so to avoid having to account for such closures to local electorates. This potentially significant change to the balance of the separation of powers was therefore uncontroversial. By contrast politicians valued the potential for patronage involved in judicial appointments, and so have been less willing to relinquish control in that area. Reform to judicial discipline has yet to become politically urgent enough to justify the parliamentary time required to enact Judicial Council legislation. In protecting judicial independence and reforming judicial governance in Ireland, getting the politics right is key.

\footnotetext{
${ }^{103}$ See https://aji.ie/press-release-26-june-2017/ [last accessed Sept. 15 2017].

${ }^{104}$ Private correspondence with the author.
} 